\title{
STUDIES ON STRUCTURE DIURETIC ACTIVITY RELATIONSHIPS OF ORGANIC COMPOUNDS OF MERCURY ${ }^{1}$
}

\author{
By R. H. KESSLER, ${ }^{2}$ R. LOZANO, ${ }^{3}$ and R. F. PITTS \\ (From The Department of Physiology, Cornell University Medical College, Ncw York, N. Y.)
}

(Submitted for publication December 3, 1956; accepted January 10, 1957)

The mercurial diuretics in common use today exhibit certain basic similarities in structure. All are mercurated derivatives of substituted three carbon compounds of the type indicated below. in which the three substituents are designated $\mathrm{X}, \mathrm{OY}$, and $\mathrm{R}$.<smiles>[X]CC([1H])C([1H])C([R])[2H]</smiles>

According to Friedman (1), the nature of the $\mathrm{X}$ substituent (usually halogen, theophylline or thioglycolate) has no effect on diuretic potency if the compound is given intravenously, but does influence both hyperacute (cardiac and respiratory arrest) and acute ( 7 to 14-day) renal toxicity. The nature of the OY group is determined by the solvent in which the mercuration is carried out and is an hydroxyl group, if the solvent is water. or a methoxy or ethoxy group, if the solvent is the corresponding alcohol. Within these limits, i.e., $\mathrm{OH}, \mathrm{OCH}_{3}$, or $\mathrm{OC}_{2} \mathrm{H}_{5}$, the nature of the $\mathrm{OY}$ group is without appreciable effect on either diuretic potency or toxicity. In contrast, the nature of the $\mathrm{R}$ group, which is commonly rather complex, has a very great effect on both toxicity and diuretic activity. In the diuretic mersalyl, $\mathrm{R}$ is o-carbamylphenoxyacetic acid; in mercaptomerin, $\mathrm{R}$ is camphoramic acid; in meralluride, $\mathrm{R}$ is succinyl-urea; in chlormerodrin, $\mathrm{R}$ is urea; and in mercumatilin, $\mathrm{R}$ is coumarin. Much of the interest in the structure-activity relationships of mercurial compounds has centered around the effects of modification of $\mathrm{R}$ and relatively less attention has been paid to simple organo-mercurial compounds.

A wide variety of substituted allyl compounds

1 Aided by grants from the National Heart Institute, National Institutes of Health and the Life Insurance Medical Research Fund.

2 Fellow of the Life Insurance Medical Research Fund.

3 Fellow of the Rockefeller Foundation. are available or easily prepared as starting materials. Mercuration in methyl alcohol is relatively easy and yields of the 3-mercuri-2-methoxy propyl end products are satisfactory. Logical questions which arise include: Is the three carbon side chain of the presently used diuretics an essential or optimal element of diuretic structure, or is it merely a matter of preparative convenience?

The diuretic activity of organic mercurial compounds has recently been ascribed to inhibition of sulfhydryl enzymes concerned with the renal tubular reabsorption of sodium and chloride ions $(2,3)$. Mercuric chloride and certain relatively simple organo-mercurials, including bromomercuri-methane, bromo-mercuri-benzene and parachloromercuri-benzoate, are potent and more or less specific inhibitors of sulfhydryl enzymes in iitro $(4,5)$. Are these compounds also diuretics and are their diuretic activities in any way related to their activities as enzyme inhibitors?

Mercuhydrin ${ }^{\circledR}(6,7)$ and Neohydrin ${ }^{\circledR}(8,9)$ have been shown to disappear rapidly from the blood stream following intravenous administration and to accumulate in the renal cortex in high concentration. Both drugs are highly bound to plasma proteins, hence are sparingly filtered through the glomerular capillaries, yet both are rapidly eliminated in the urine. Accordingly, tubular secretion must play a role in their excretion. Is rate of removal from plasma, rapidity of uptake by the renal cortex or rate of secretion by the renal tubules correlated with diuretic activity?

The present study was undertaken to answer the three questions posed above: (a) is the three carbon side chain essential for diuretic action; (b) are sulfhydryl enzyme inhibitors necessarily diuretics; and (c) can diuretic activity be related to distribution and fate of the mercurial compound in the body. Twelve organic compounds of mercury and the single inorganic compound, mercuric chloride, were synthesized in our laboratory using $\mathrm{Hg}^{203}$ as a label. Each compound was adminis- 
tered intravenously to anesthetized dogs in doses of 1,2 , and $4 \mathrm{mg}$. of mercury per kilo of body weight. In all, over 50 experiments have been performed on an equal number of dogs. All experiments were acute for it was necessary to sacrifice each animal in order to obtain tissue samples. If one disregards mercuric chloride, which is moderately effective as a diuretic, the structure which we have observed to be associated with diuretic activity includes (a) a chain of not less than 3 carbon atoms, (b) an atom of mercury attached to the terminal carbon of this chain and (c) some hydrophilic group not less than 3 carbons distant from the mercury. Probably other structures are compatible with diuretic activity; however, many are not. All mercurial compounds are concentrated to some degree in the renal cortex, yet the degree of concentration seems but little related to diuretic potency. Those compounds which are very slowly excreted have no diuretic activity whereas those which are most rapidly excreted are, with one exception, diuretics. However, this exception is sufficiently striking to discourage attaching great significance to a correlation of urinary mercury excretion and diuretic potency. Finally, three of the compounds most widely used as inhibitors of sulfhydryl enzymes in vitro are without diuretic activity. Thus, if diuresis is related to inhibition of sulfhydryl enzymes, the inhibitors must have properties other than, or structures different from those of bromomercuri-methane, bromomercuribenzene and p-chloromercuri-benzoate.

\section{METHODS}

\section{Chemical}

All syntheses were performed in our laboratory starting with the radioisotope $\mathrm{Hg}^{200} \mathrm{O}$. As shipped from Oak Ridge National Laboratories, this product contains 3 curies of $\mathrm{Hg}^{10}$ per irradiation unit, with a half life of 2.71 days. To avoid using material of high and rapidly changing activity, the isotopic mixture was allowed to stand for two weeks or more prior to use. The isotope $\mathrm{Hg}^{203}$ has a half life of 43.5 days and emits beta particles of $0.205 \mathrm{MEV}$. and gamma rays of $0.286 \mathrm{MEV}$. When first used, the organic mercurial compounds counted at a rate of approximately 4,000 per minute per microgram of mercury in a well-type scintillation unit. They were used for two or at most three half life periods; some required recrystallization one or more times during this interval because of decomposition with liberation of metallic mercury, which strangely did not occur with the non-radioactive compounds nor with all of the radioactive ones.
We are indebted to Dr. H. L. Friedman of Lakeside Laboratories, Inc. for directions for the preparation of chlormerodrin and meralluride and also for a supply of both the allylurea and the succinylallylurea used as starting materials. We are similarly indebted to Dr. C. M. Suter, of the Sterling-Winthrop Research Institute for advice on the preparation of mersalyl and for a supply of o-allylcarbamyl-phenoxyacetic acid. The remainder of the syntheses were taken from the literature and the appropriate references are noted in Table I.

All syntheses were performed several times with nonradioactive mercury prior to a radioactive run. Structures of end products were not proved. However, criteria of adequacy of preparation included reproducibility of product, melting point, solubility characteristics and gravimetric mercury analysis as the sulfide. Brief descriptions of these characteristics of the compounds synthesized are included in Table I.

Chemical procedures employed in the analyses of blood, urine and tissue samples are those described in a previous communication (9).

\section{Biological}

With one exception, 4 identical procedures were followed in all experiments. All were performed on female mongrel dogs, anesthetized with not more than 30 mg. of pentobarbital per kilo intravenously, supplemented as needed. Following anesthesia, one liter of 0.85 per cent saline was administered intravenously, a priming dose of creatinine was given and an infusion of creatinine in saline was begun at a rate of $2 \mathrm{cc}$. per minute. The left kidney was exteriorized through a $5-\mathrm{cm}$. flank incision and held in contact with an end window Geiger tube by a sheet of rubber dam perforated to pass the renal pedicle. A film of Saran plastic separated the kidney from the Geiger tube to protect the latter from contamination. Counts were recorded every minute and represent semiquantitatively variations in the concentration of radiomercury in the outer few millimeters of the renal cortex. When urine flow stabilized, two 20-minute control clearance periods were obtained. Blood samples were drawn through a retention needle in the femoral artery, urine was collected with a Foley catheter and the bladder was washed out with $10 \mathrm{cc}$. of distilled water at the end of each urine collection period.

The mercury compound, dissolved with a minimum of alkali or alcohol, if the solubility was greater in the latter solvent, was administered intravenously in $20 \mathrm{sec}$ onds following the second control clearance period. Each compound was given in three experiments in doses of 1 , 2 and $4 \mathrm{mg}$. mercury per kilo body weight. Arterial blood samples were drawn 1, 2, 3, 5, 7, 10 and 15 minutes after the start of the mercury injection and thereafter

4 In this experiment, designed to test the effects of Probenecidis on the secretion of p-chloromercuri-benzoate, the mercurial compound was infused intravenously throughout the course of the experiment instead of being administered rapidly in a single intravenous injection. 
at the mid-point of each urine collection period. The first two clearance periods following mercury were 10 minutes in length. Thereafter, 20-minute collections were continued for a total of 3 hours.

At the end of the experiment, the animal was sacrificed and samples of heart, lung, diaphragm, gut, skin, liver and spleen were removed. One kidney was cored from cortex through medullary papilla with a No. 5 cork borer. The cylinder of tissue so obtained was sliced free hand with a razor blade into nine or ten sections as nearly equal in thickness as possible. Usually three sections were obtained from the cortex, three from the medulla and four from the papilla. The kidney sections (weighing 15 to $60 \mathrm{mg}$.) and samples of the other tissues of appropriate size were placed in tared test tubes, weighed wet and counted without further preparation in a well-type scintillation unit. Plasma binding of each mercurial compound was estimated by high pressure ultrafiltration of plasma through cellophane.

\section{RESULTS}

The 13 compounds studied are listed in Table I in order of decreasing complexity, modified to place last the four compounds used in vitro as sulfhydryl enzyme inhibitors. When arranged in this order, the first five compounds have diuretic properties, the next seven are not diuretics, and the final one, mercuric chloride, is again a diuretic.

We have taken as an indication of diuretic activity, an increase in urine flow or an increase in sodium excretion with respect to the two control periods in any period within three hours after the intravenous injection of an amount of the compound containing 1,2 , or $4 \mathrm{mg}$. of mercury. We have been fortunate in the application of these cri-

TABLE I

Structures, physical properties and methods of preparation and purification of the one inorganic and twelve organic compounds of mercury used in these studies*

\begin{tabular}{|c|c|c|c|c|c|c|c|}
\hline \multirow{3}{*}{ 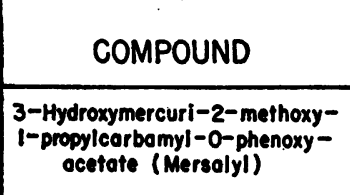 } & \multirow{2}{*}{ FORMULA } & \multirow{2}{*}{$\begin{array}{l}\text { RECRYSTAL- } \\
\text { IZATION } \\
\text { SOLVENT } \\
\end{array}$} & \multicolumn{2}{|c|}{$\begin{array}{l}\text { MELTING } \\
\text { POINT }\end{array}$} & \multicolumn{2}{|c|}{$\begin{array}{c}\mathcal{X} \\
\text { MERCURY }\end{array}$} & \multirow{2}{*}{$\begin{array}{l}\text { REFER- } \\
\text { ENCE }\end{array}$} \\
\hline & & & Reported & Found & Colc. & Obs. & \\
\hline & $\mathrm{HO}-\mathrm{Hg}-\mathrm{CH}_{2}-\mathrm{CH}_{3}-\mathrm{CH}_{2}-\mathrm{NH}-\mathrm{C}-\overbrace{-\mathrm{CH}_{2}-\mathrm{COOH}}^{\longrightarrow}$ & Water & - & - & 41.6 & 42.6 & A \\
\hline $\begin{array}{l}\text { 3-Acetomercuri-2-methoxy- } \\
\text { sucelnyl-propylureo } \\
\text { (Merolluride) }\end{array}$ & 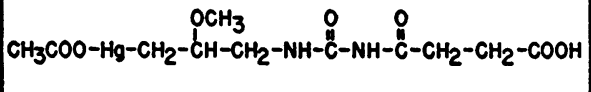 & Ethonol & $\mid 177-8 \frac{1}{2}$ & 178 & 40.9 & 42.8 & $\mathbf{B}$ \\
\hline $\begin{array}{l}\text { 3-Chloromercurl-2-methoxy- } \\
\text { propylurea } \\
\text { (Chlormerodrin) }\end{array}$ & $\underset{\mathrm{Cl}}{\stackrel{\mathrm{H}}{\mathrm{O}}-\mathrm{CH}_{2}-\mathrm{CH}_{3}} \stackrel{\mathrm{C}}{\mathrm{C}}-\mathrm{CH}_{2}-\mathrm{NH}-\stackrel{\mathrm{U}}{\mathrm{C}}-\mathrm{NH}_{2}$ & Ethanol & $\mid 152-3$ & 153 & 54.6 & 54.7 & B \\
\hline $\begin{array}{l}\text { 3-Acetomercuri -2-methoxy - } \\
\text { 1-hydroxy - propone }\end{array}$ & 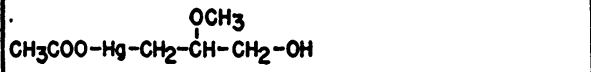 & Methanol & - & 162 & 57.6 & 58.2 & B \\
\hline $\begin{array}{l}\text { 3-Nitromercuri-2,3-dehydro- } \\
\text { 1-hydroxy-propane }\end{array}$ & $\mathrm{NO}_{3}-\mathrm{Hg}-\mathrm{CH}=\mathrm{CH}-\mathrm{CH}_{2}-\mathrm{OH}$ & Woter & 271 & 260 & 628 & 62.8 & C \\
\hline 3-Bromomercuri-propone & $\mathrm{Br}-\mathrm{Hg}-\mathrm{CH}_{2}-\mathrm{CH}_{2}-\mathrm{CH}_{3}$ & Ethanol-Woter & 134 & $132-5$ & 一 & 一 & D \\
\hline $\begin{array}{c}\text { 3-lodomercuri -2-hydroxy- } \\
\text { propone }\end{array}$ & 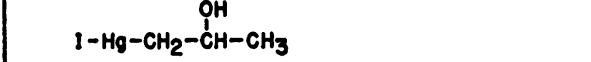 & Ethanol-Water & 68 & 68 & 55.4 & 56.0 & $\mathbf{E}$ \\
\hline $\begin{array}{c}\text { 2-Chloromercurl-1-methoxy- } \\
\text { ethone }\end{array}$ & $\mathrm{Cl}-\mathrm{Hg}_{\mathrm{g}}-\mathrm{CH}_{2}-\mathrm{CH}_{2}-\mathrm{OCH}_{3}$ & Water & 68 & 68 & 68.1 & 70.0 & D \\
\hline $\begin{array}{c}\text { 2-Chloromercurl-1-hydroxy- } \\
\text { ethone }\end{array}$ & $\mathrm{Cl}-\mathrm{Hg}-\mathrm{CH}_{2}-\mathrm{CH}_{2}-\mathrm{OH}$ & Methanol & $155-6$ & 157 & 73.0 & 73.3 & D \\
\hline p-Chloromercuri - benzoote & $\mathrm{Cl}-\mathrm{Hg}-\longrightarrow-\mathrm{COOH}$ & Woter & 273 & 273 & 一 & 一 & $\mathbf{F}$ \\
\hline Bromomercuri- benzene & $\mathrm{Br}-\mathrm{Hg}-$ & Pyridine & 275 & $274-6$ & - & 一 & G \\
\hline Bromomercuri - methone & $\mathrm{Br}-\mathrm{H}_{9}-\mathrm{CH}_{3}$ & Ethonol-Water & 160 & 165 & 一 & 一 & D \\
\hline Mercuric Chloride & $\mathrm{Hg}-\mathrm{Cl}_{2}$ & Water & - & - & - & - & 一 \\
\hline
\end{tabular}

* Procedures employed in the syntheses of these several compounds were derived from the following sources: A, Personal communication from Dr. H. L. Friedman, Lakeside Laboratories, Inc.; B, personal communication from Dr. C. M. Suter, Sterling-Winthrop Research Institute; C, K. Hoffman and J. Sand, Berichte der Deutschen Chemischen Gesellshaft, 1900, p. 2692; D, S. W. Whitmore, Organic Compounds of Mercury, 1921, Chemical Catalogue Co., New York; E, J. Sand and K. Hoffman, Berichte der Deutschen Chemischen Gesellshaft, 1900, p. 1353; F, H. Gilman and A. Blatt, Organic Syntheses, Vol. I, 1941, John Wiley \& Sons, New York; G, S. Hilpert and G. Gruttner, Berichte der Deutschen Chemischen Gesellshaft, 1913, p. 1675. 


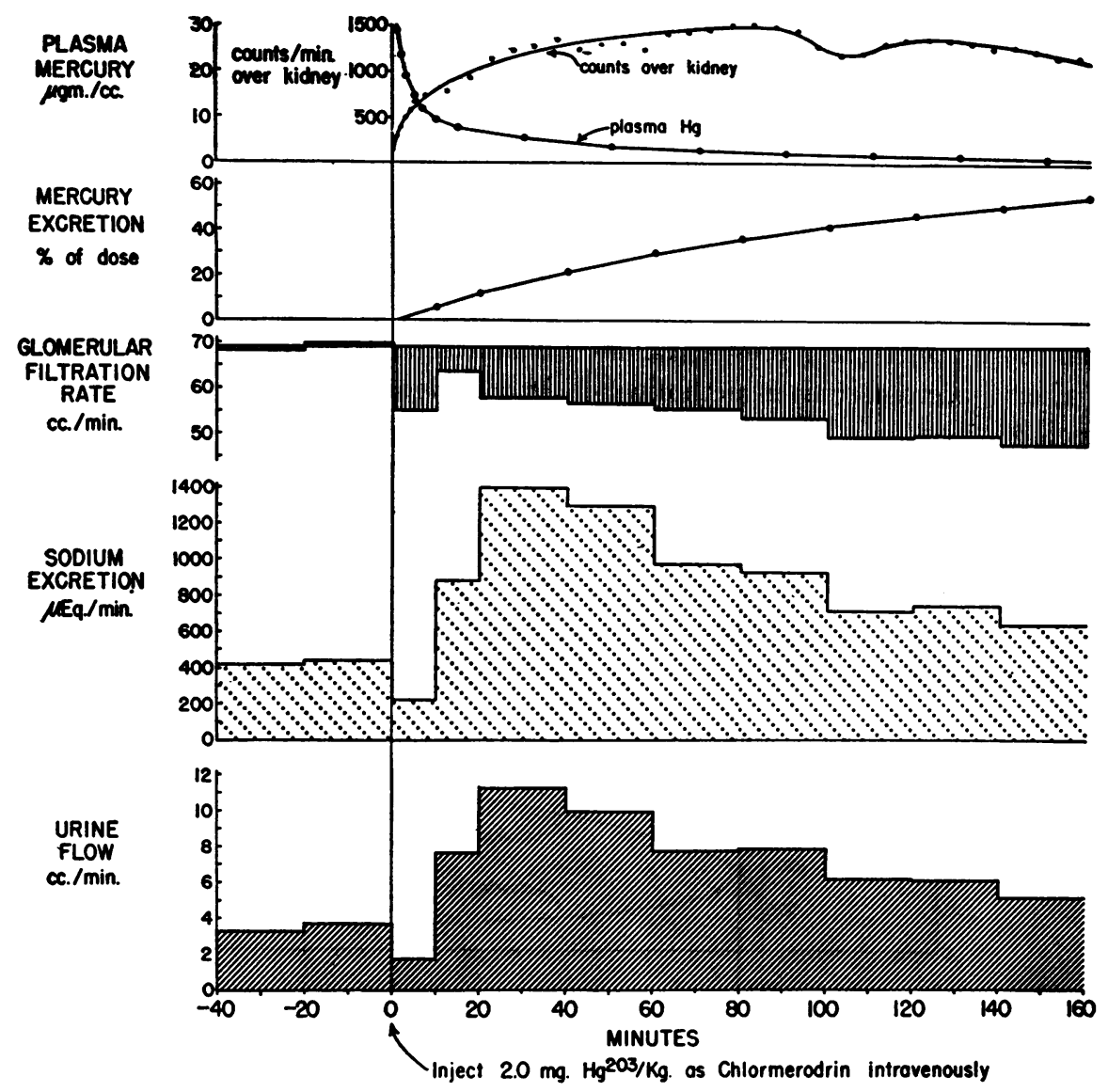

Fig. 1. Summary of Data Obtained in an Experiment in Which a Diuretic Compound, Chlormerodrin, Was Administered Intravenously in a Dose of 2.0 mg. OF MERCURY PER KIIO

See text for further description.

teria to find that any compound increasing urine flow also increased sodium excretion; that any compound (except $\mathrm{HgCl}_{2}$ ) 5 which has a diuretic action in one dose, exhibited such an action in all three doses; and that any compound which significantly increased urine flow or sodium excretion in one 20-minute collection period, did so in several consecutive periods. There has, therefore, been no difficulty in deciding, according to these criteria, whether a compound is or is not a diuretic. These criteria are, of course, remarkably restrictive, especially with respect to time, but we feel, by defining diuresis in such terms in the dog, we are studying a phenomenon related to that observed in the

5 The single exception refers to the fact that mercuric chloride in the highest dose (4 mg. of mercury per kilo) caused a drop in urine flow and in sodium excretion in association with a collapse of filtration rate. successful therapy of edematous patients. We are not convinced that the "diuresis" observed in rabbits by Fourneau and Melville (10), having its onset three days after a single intravenous injection, has any bearing on diuretic therapy.

Figures 1 and 2 summarize experiments in which two organo-mercurial compounds having diuretic properties were administered in doses of $2 \mathrm{mg}$. of mercury per kilo of body weight: Figure 1, chlormerodrin; Figure 2, 3-acetomercuri-2methoxy-1-hydroxy-propane.

The significant features of the diuretic responses in these experiments are the following: sodium excretion increased from a mean of $427 \mathrm{mEq}$. per minute before, to a peak of $1,395 \mathrm{mEq}$. per minute after chlormerodrin and from a mean of $423 \mathrm{mEq}$. per minute before, to a peak of $1,040 \mathrm{mEq}$. per minute after 3-acetomercuri-2-methoxy-1-hydroxy- 
propane. In both instances, the peak sodium output occurred during the period 20 to 40 minutes after administration of the mercurial compound. Urine flow, like sodium excretion, increased two to three fold in the two experiments and in each, the peak was reached during the 20 to 40 -minute period. The diuretic response both in terms of sodium loss and excess urine output was greater in magnitude and more prolonged following chlormerodrin than after 3-acetomercuri-2-methoxy-1hydroxy-propane.

The plasma mercury concentration in both experiments was roughly $30 \mathrm{mcgm}$. per cc. one minute after the intravenous injection, dropped rapidly over the first half hour and then more slowly to reach values of one and three mcgm. per cc. three hours later. The regression of plasma concen- tration is obviously a multiple exponential function of time. No less than three processes determine the characteristics of this regression curve, namely, mixing in the plasma compartment, migration into tissues and excretion $(6,9)$.

Migration from plasma into kidney tissue or, more specifically, uptake and binding of mercury by cells of the renal cortex are illustrated semiquantitatively by the counts per minute recorded by a Geiger tube in contact with the exteriorized kidney. Because a Geiger tube is appreciably sensitive only to beta particles, and because the energy of the beta emission of mercury is low, the system responds mainly to mercury in the outer few millimeters of the kidney cortex. It is apparent that both chlormerodrin and 3-acetomercuri-2-methoxy-1-hydroxy-propane are rapidly

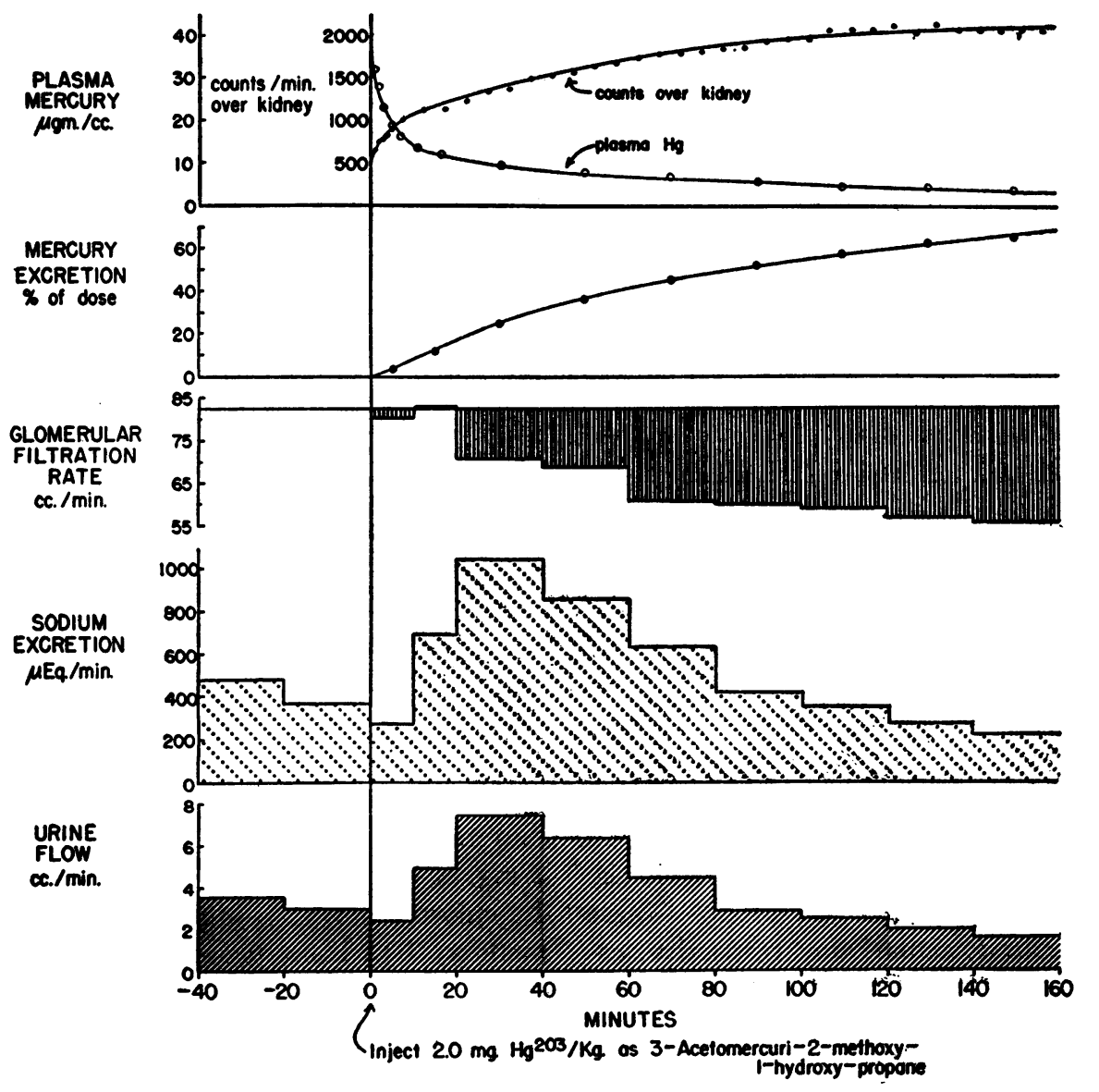

Fig. 2. Summary of Data Obtamed in an Expermenent in Which a Diuretic Compound, 3-Acetomercuri-2-Methoxy-1-Hydroxy-Propane, Was Administered InTravenously in a Dose of 2.0 Mg. OF Mercury PER KHO

See text for further description. 
TABLE II

Comparison of tissue concentrations and tissue to plasma concentration ratios of mercury following the administration of two compounds having diuretic properties*

\begin{tabular}{|c|c|c|c|c|}
\hline \multirow[b]{3}{*}{ Kidney Cortex } & \multicolumn{2}{|c|}{ Chlormerodrin } & \multicolumn{2}{|c|}{$\begin{array}{c}\text { 3-Acetomercuri-2-Methoxy } \\
\text { 1-Hydroxy-Propene }\end{array}$} \\
\hline & $\mu \mathrm{gm} . \mathrm{Hg} / \mathrm{gm}$ & \begin{tabular}{|c|} 
Tissuel \\
Plosmo
\end{tabular} & $\mu \mathrm{gm} \cdot \mathrm{Hg} / \mathrm{gm}$ & $\begin{array}{l}\text { Tissuef } \\
\text { Plosme }\end{array}$ \\
\hline & 155 & 144 & 38.9 & 12.2 \\
\hline Liver & 3.89 & 3.60 & 5.45 & 1.70 \\
\hline Spleen & 1.39 & 1.29 & 3.16 & 0.99 \\
\hline Lung & 1.23 & 1.20 & 4.32 & 1.35 \\
\hline Heart & 0.29 & 0.28 & 2.59 & 0.80 \\
\hline Gut & 0.70 & 0.66 & 2.59 & 0.80 \\
\hline Diaphragm. & 0.23 & 0.21 & 0.84 & 0.26 \\
\hline Skin & 0.40 & 0.35 & 1.95 & 0.61 \\
\hline
\end{tabular}

* In each experiment, an amount of the compound containing $2.0 \mathrm{mg}$. of mercury per kilo was administered intravenously. The animals were sacrificed $3 \mathrm{hrs}$. after receiving the injection. These data were obtained from the two experiments summarized in Figures 1 and 2.

taken up by cortical tissue, half the maximum concentration being attained in 15 minutes. The concentration of chlormerodrin in the kidney reached a peak about one and one-half hours after intravenous injection and then gradually declined. In contrast, the concentration of 3-acetomercuri-2methoxy-1-hydroxy-propane increased somewhat more gradually and reached a plateau between two and three hours after injection.

The concentration of mercury in the renal cortex and in representative tissues at the end of each of these two experiments are given in Table II. It is evident that the kidney concentrates each substance highly with respect to plasma, that the liver, spleen and lung concentrate them very slightly and that the remaining tissues do not concentrate them at all.

The rate of excretion of mercury, in per cent of dose administered, and the glomerular filtration rate, as measured by the creatinine clearance, are also given in Figures 1 and 2. Excretion of mercury was rapid following both mercurial compounds and in the two hours and forty minutes following intravenous administration; 54.9 per cent of the chlormerodrin and 66.6 per cent of the 3-acetomercuri-2-methoxy-1-hydroxy-propane were eliminated in the urine. The two compounds exhibited equivalent toxicity in a dose of $2 \mathrm{mg}$. of mercury per kilo when toxicity is expressed in terms of depression of glomerular filtration rate. In both experiments, the creatinine clearance dropped about 30 per cent following the mercurial.

In Table III are summarized data obtained in 18 experiments with six compounds which exhibited diuretic activity. Each compound was given in a dose of 1,2 , and $4 \mathrm{mg}$. of mercury per kilo. For comparison, the commonly used human therapeutic dose of most mercurial diuretics amounts to $1 \mathrm{mg}$. of mercury per kilo. Each experiment was performed in a manner similar to that of the experiments illustrated in Figures 1 and 2.

In each instance (with the exception of mercuric chloride in a dose of $4 \mathrm{mg}$. of mercury per kilo) both urine flow and sodium excretion increased after the drug. Furthermore, the diuresis of water and sodium was greater after a dose of $2 \mathrm{mg}$. of mercury per kilo than after a dose of 1 $\mathrm{mg}$. For the most part, the response to $4 \mathrm{mg}$. of mercury per kilo was equal to or less than that to $2 \mathrm{mg}$. Only 3-acetomercuri-2-methoxy-1-hydroxy-propane exhibited a greater diuretic response to $4 \mathrm{mg}$. of mercury per kilo.

All compounds in all dose ranges (with two exceptions in the 18 experiments) depressed glomerular filtration rate. ${ }^{\circ}$ Depression for the most part was slight to moderate, although greater in the higher dosage range. However, what must have been individual differences in susceptibility complicated the picture. Of all the compounds studied, 3-acetomercuri-2-methoxy-succinylpropylurea appeared most benign, mercuric chloride most toxic.

All of the diuretic compounds of mercury shown in Table III are more or less rapidly eliminated in the urine. From 10 to 70 per cent of the dose was excreted in the two hours and forty minutes after intravenous administration. The clearance ${ }^{7}$ of mercury ranged from 7 to $45 \mathrm{cc}$. per minute. Since these compounds were from 99.4 to essentially 100 per cent bound by plasma proteins, they

- Depression of filtration rate is no doubt due in part to the rapidity of intravenous injection of the diuretic, i.e., 20 seconds.

7 Because of the rapid uptake of the mercurial compounds by the renal tubules early in the course of the experiment, their combination with cysteine in the tubular cells and their secretion into the urine, clearance has a somewhat different connotation than it usually has. 


\section{TABLE III}

Summary of results obtained in 18 experiments in which six diuretic compounds were administered intravenously in doses of 1,2 and $4 \mathrm{mg}$. of mercury per kilo*

\begin{tabular}{|c|c|c|c|c|c|c|c|c|c|c|c|c|c|c|}
\hline \multirow{6}{*}{$\begin{array}{c}\text { 3-Hydroxymercuri-2-methoxy- } \\
\text { 1-propylcarbamyl-o-phenoxy- } \\
\text { acetate- (Mersalyl) }\end{array}$} & \multirow{6}{*}{\begin{tabular}{|c|} 
Dose \\
mg. Ho \\
/Kg: \\
\\
1 \\
2 \\
4 \\
\end{tabular}} & \multirow{3}{*}{\multicolumn{2}{|c|}{ 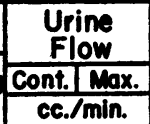 }} & \multirow{3}{*}{\multicolumn{2}{|c|}{\begin{tabular}{|c|} 
Na \\
Excretion \\
Cont. $/$ Max. \\
$\mu E q /$ min. \\
\end{tabular}}} & \multirow{3}{*}{\multicolumn{2}{|c|}{\begin{tabular}{|c|}
$\begin{array}{c}\text { Greatinine } \\
\text { Clearance }\end{array}$ \\
Cont. $\mid$ Max. \\
ca/min. \\
\end{tabular}}} & \multicolumn{2}{|c|}{ Mercury } & \multicolumn{5}{|c|}{ Temind Mercury Concentration } \\
\hline & & & & & & & & \multirow{2}{*}{\begin{tabular}{|l|}
$\%$ \\
Dose \\
Excr.
\end{tabular}} & \multirow{2}{*}{\begin{tabular}{|c|}
$\mathrm{C}_{\mathrm{Hg}}$ \\
${ }_{\text {cmin. }}$ \\
\end{tabular}} & \multirow{2}{*}{\multicolumn{2}{|c|}{ 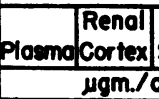 }} & \multirow{2}{*}{\multicolumn{2}{|c|}{ Spleenliviv }} & \\
\hline & & & & & & & & & & & & & & \\
\hline & & 1.1 & 1.9 & 190 & 400 & 62 & 67 & 67 & 34 & 0.5 & 9 & 0.1 & 0.6 & 0.2 \\
\hline & & 2.7 & 8.5 & 360 & 980 & 64 & 52 & 62 & 25 & 1.2 & 10 & 1.1 & 0.8 & 0.1 \\
\hline & & 3.2 & 4.8 & 130 & 540 & 43 & 28 & 46 & 20 & 2.4 & 19 & 1.8 & 2.5 & 0.4 \\
\hline \multirow{3}{*}{$\begin{array}{l}\text { 3-Acetomercuri-2-methoxy- } \\
\text { succinyl-propylurea } \\
\text { (Meralluride) }\end{array}$} & 1 & 18 & 4.8 & 270 & 630 & 68 & 62 & 59 & 26 & 1.0 & 9 & 0.6 & 0.7 & 0.2 \\
\hline & 2 & 3.1 & 7.9 & 230 & 910 & 64 & 53 & 74 & 34 & 1.3 & 22 & 0.6 & 0.8 & 0.8 \\
\hline & 4 & 3.2 & 7.3 & 560 & 1160 & 66 & 71 & 61 & 20 & 6.0 & 72 & 2.4 & 3.7 & 0.7 \\
\hline \multirow{3}{*}{$\begin{array}{l}\text { 3-Chloromercuri-2-methoxy- } \\
\text { propylurea } \\
\text { (Chlormerodrin) }\end{array}$} & 1 & 1.6 & 10. & 150 & 1290 & 51 & 45 & 48 & 26 & 0.8 & 75 & 0.3 & 2.2 & 0.2 \\
\hline & 2 & 3.5 & II. & 420 & 1340 & 69 & 49 & 55 & 45 & 1.1 & 150 & 1.4 & 3.4 & 0.2 \\
\hline & 4 & 3.5 & 6.5 & 98 & 760 & 71 & 34 & 26 & 22 & 5.2 & 390 & 9.1 & 8.5 & 0.8 \\
\hline \multirow{3}{*}{$\begin{array}{l}\text { 3-Acetomercuri-2-methoxy- } \\
\text { I-hydroxy-propane }\end{array}$} & 1 & 4.4 & 6.8 & 720 & 930 & 84 & 72 & 53 & 15 & 1.2 & 15 & 2.4 & 2.3 & 0.3 \\
\hline & 2 & 3.3 & 6.9 & 430 & 950 & 83 & 57 & 67 & 15 & 3.2 & 39 & 3.2 & 5.5 & 0.8 \\
\hline & 4 & 3.6 & 8.8 & 370 & 1020 & 68 & 43 & 41 & 12 & 5.7 & 45 & 13. & 9.4 & 1.3 \\
\hline \multirow{3}{*}{$\begin{array}{c}\text { 3-Nitromercuri-3-2-dehydro- } \\
\text { I-hydroxy-propane }\end{array}$} & 1 & 1.3 & 4.1 & 140 & 520 & 43 & 28 & 52 & 7.2 & 2.1 & 31 & 3.5 & 3.8 & 0.6 \\
\hline & 2 & 3.0 & 9.6 & 420 & 1300 & 65 & 50 & 10 & 7.4 & 2.1 & 23 & 24. & 4.8 & 0.6 \\
\hline & 4 & 2.0 & 8.8 & 200 & 1190 & 53 & 45 & 35 & 9.6 & 10. & 68 & 60. & 17. & 1.7 \\
\hline \multirow[t]{3}{*}{ Mercuric Chloride } & 1 & 4.2 & 6.9 & 470 & 850 & 58 & 48 & 23 & 9.0 & 1.6 & 54 & 40. & 5.1 & 0.2 \\
\hline & 2 & 3.2 & 8.4 & 450 & 1260 & 53 & 35 & 21 & 9.0 & 2.9 & 120 & 74. & 6.7 & 0.3 \\
\hline & 4 & 0.8 & 0.4 & 92 & 37 & 45 & 2 & 4 & 1.8 & 8.3 & 240 & 31. & 13. & 1.2 \\
\hline
\end{tabular}

* Urine flow, sodium excretion and creatinine clearance are presented as averages of the values observed in the two control periods and in the two successive experimental periods in which maximum changes occurred. Mercury excretion is presented both in terms of per cent of the administered dose eliminated in the 3 hrs. following intravenous injection of the diuretic and in terms of the maximum plasma clearance of mercury. In the last 5 columns on the right are shown the mercury concentrations of plasma and of four representative tissues observed at the end of the experiment.

We have no explanation for the aberrant result on mercury excretion obtained in the experiment in which 2.0 mg. of mercury was administered as 3-nitromercuri-3-2-dehydro-1-hydroxy-propane. Only 10 per cent of the administered dose was excreted in comparison with the 52 and 35 per cent excreted at lower and higher dose levels. The clearance, however, is correctly tabulated for plasma concentration was proportionately as low as urinary excretion.

must have been in large part actively secreted into the tubular urine, for no significant amount is free to enter the glomerular filtrate.

The concentration of mercury in the plasma and in four representative tissues at the end of each of the several experiments are shown on the right of Table III. All of the diuretic compounds are more highly concentrated in the renal cortex than in any other tissue, the greatest absolute concentration of mercury being attained following a dose of 3-chloromercuri-2-methoxypropyl-urea (chlormerodrin) equivalent to $4 \mathrm{mg}$. of mercury per kilo. The concentration attained in this ex- periment was $390 \mathrm{mcgm}$. per gm., roughly $2 \times$ $10^{-3}$ molar mercury. Significant concentrations of mercury were attained in the spleen and liver. Two compounds, namely 3-nitromercuri-2-3-dehydro-1-hydroxy-propane and mercuric chloride were rather highly concentrated in the spleen. Lung, heart, gut, skin and diaphragm concentrated the mercury slightly or not at all. Least active in this respect was diaphragm, shown in the last column of Table III.

Figures 3 and 4 summarize experiments in which two organo-mercurial compounds exhibiting no diuretic activity were administered in doses of 
$2 \mathrm{mg}$. of mercury per kilo of body weight: Figure 3, p-chloromercuri-benzoate; Figure 4, 3-iodomercuri-2-hydroxy-propane. Urine flow and sodium excretion decreased after the injection of both compounds, similar decreases occurring at all dose levels within the range of $1 \mathrm{and} 4 \mathrm{mg}$. of mercury per kilo. Although this antidiuresis in the p-chloromercuri-benzoate experiment was associated with a modest fall in filtration rate, no such fall was observed following 3-iodomercuri-2-hydroxy-propane. Furthermore, following doses of 1 and $4 \mathrm{mg}$. per kilo of mercury as p-chloromercuri-benzoate, lesser falls in filtration rate occurred with equivalent antidiureses.

The plasma concentration of mercury decreased from a peak of $31 \mathrm{mcgm}$. per cc. one minute after the intravenous injection of p-chloromercuri-benzoate to a low of $4 \mathrm{mcgm}$. per cc. two hours and fifty minutes later. The plasma regression curve was very similar to that following 3-acetomercuri2-methoxy-1-hydroxy-propane. In contrast the regression curve following 3-iodomercuri-2-hydroxy-propane was very different, the peak value one minute after injection amounting only to 2.78 mcgm. per cc. A plateau of $0.4 \mathrm{mcgm}$. per cc. was attained after an hour and was maintained for the remainder of the experiment.

Uptake of mercury by the renal cortex, as measured by a Geiger tube in contact with the kidney surface, was very rapid in both experiments; half the peak concentration of each compound was attained within 1 to 2 minutes. However, the concentration of p-chloromercuri-benzoate reached a plateau early, whereas that of 3-iodomercuri-2-hydroxy-propane continued to rise throughout the experiment. Early plateau-

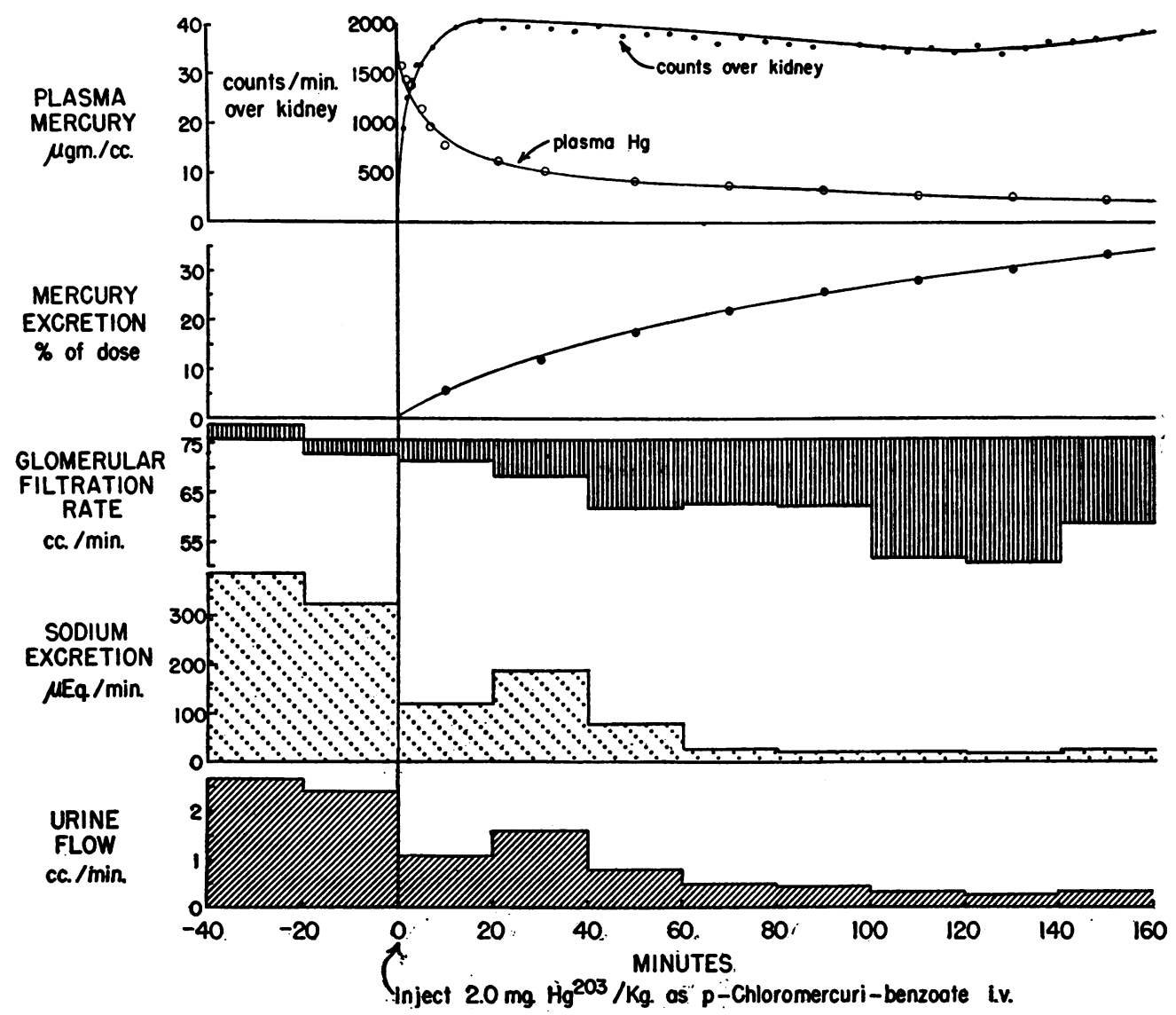

Fig. 3. Summary of Data Obtained in an Experiment in Which a Non-Diuretic Compound, p-Chloromercuri-Benzoate, Was Administered Intravenously in a Dose of 2.0 MG. OF MERCURY PER KIIO

See text for further description. 


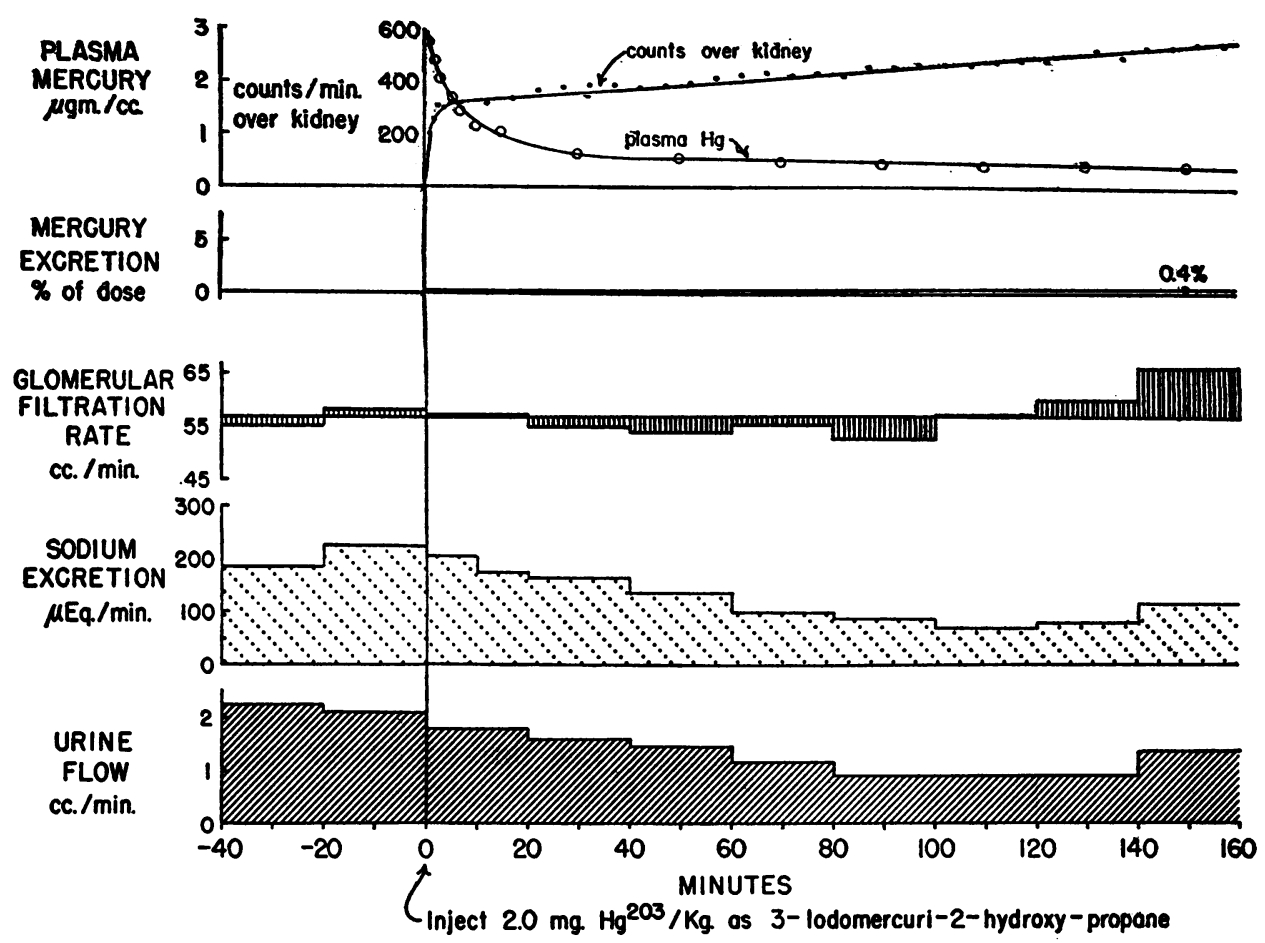

Fig. 4. Summary of Data Obtained in an Experiment in Which a Non-Diuretic Compound, 3-Iodomercuri-2-Hydroxy-Propane, Was Administered Intravenously in a Dose of 2.0 MG. OF MERCURY PER KIIO

See text for further description.

ing of p-chloromercuri-benzoate is no doubt related to its rapid urinary excretion, the continued slow rise of 3-iodomercuri-2-hydroxy-propane to its negligible excretion, for renal concentration is no doubt directly proportional to rate of uptake and inversely proportional to rate of excretion.

TABLE IV

Comparison of tissue concentrations and tissue to plasma concentration ratios of mercury following the administration of two compounds devoid of diuretic properties *

\begin{tabular}{|c|c|c|c|c|}
\hline \multirow[b]{3}{*}{ Kidney Cortex } & \multicolumn{2}{|c|}{$\begin{array}{l}\text { p-Chloromercuri- } \\
\text { Benzoote }\end{array}$} & \multicolumn{2}{|c|}{$\begin{array}{l}\text { 3-lodomercuri- } \\
\text { 2-Hydroxy-Propone }\end{array}$} \\
\hline & $\mu g m . ~ H g / g m$. & \begin{tabular}{|c|} 
Tissue/ \\
Plosmo
\end{tabular} & $\mu g \mathrm{~m} . \mathrm{Hg} / \mathrm{gm}$. & \begin{tabular}{|c|} 
Tissuef \\
Plosma
\end{tabular} \\
\hline & 36.3 & 11.8 & 54.0 & 130 \\
\hline Liver & 2.79 & 0.91 & 9.75 & 23.4 \\
\hline Spleen & 2.14 & 0.70 & 69.6 & 168 \\
\hline Lung & 2.80 & 0.91 & 4.82 & 11.6 \\
\hline Heart & 0.66 & 0.21 & 1.45 & 3.50 \\
\hline Gut & 2.47 & 0.80 & 2.00 & 4.80 \\
\hline Diophragm & 0.76 & 0.25 & 2.38 & 5.72 \\
\hline Skin & 0.96 & 0.31 & 1.05 & 2.52 \\
\hline
\end{tabular}

* See legend of Table II for further clarification.
As is evident from Table IV, the final renal cortical concentration of each compound was similar to that of 3-acetomercuri-2-methoxy-1-hydroxy-propane ( $c f .$, Table II). Most striking, however, is the very high concentration of 3-iodomercuri-2-hydroxy-propane attained in the spleen, the splenic value exceeding even the renal. The hepatic concentration of this compound is also relatively high.

In Table $\mathrm{V}$ are summarized the data obtained in 21 experiments with seven compounds which exhibited no diuretic activity. Each experiment was similar to those presented in Figures 3 and 4. In no instance was there a significant increase in either urine flow or sodium excretion at any dose level within a range of 1 to $4 \mathrm{mg}$. mercury per kilo. Although six of the seven compounds caused some reduction in glomerular filtration rate, the magnitudes of the reductions were no greater than those observed to result from diuretic compounds ( $c f .$, Table III). Furthermore, each non-diuretic compound in at least one dose level failed to alter filtration rate and 2-chloro- 
mercuri-1-methoxy-ethane was remarkably benign at all dose levels.

If one excludes p-chloromercuri-benzoate, all non-diuretic compounds studied were poorly excreted whereas all diuretic compounds were rapidly eliminated in the urine. Because high rate of excretion seemed so clearly related to diuretic action with the single exception of p-chloromercuribenzoate, it was felt that this latter compound might be secreted by a different mechanism. The inference was that secretion of the diuretic compounds concentrates them at a mercury sensitive site of salt reabsorption. P-chloromercuri-benzoate, secreted by another mechanism and concentrated at another site, might thus be devoid of diuretic properties. We felt it at least possible that p-chloromercuri-benzoate might be secreted by the mechanism which transports Diodrast ${ }^{\circ}$, paraaminohippurate and penicillin and thus be sensitive to Benemid ${ }^{3}$. Evidence obtained in two experiments clearly demonstrated that Probenecid had no effect on renal uptake, regression of plasma concentration or rate of urinary excretion of p-chloromercuri-benzoate. We therefore have no evidence that this latter compound is secreted by a mechanism different from that of the diuretic compounds. Its high rate of excretion remains an exception to any generalization relating this property to diuretic activity.

It is evident from Tables III and V that all compounds, both diuretic and non-diuretic, are concentrated in the renal cortex. Although chlormerodrin, which is the most active of the diuretics studied, is also most highly concentrated in the kidney, the degree of concentration of the remaining compounds seems entirely unrelated to diuretic potency. Figure 5 illustrates the distribution of mercury in the kidney in four experiments in

TABLE V

Summary of results obtained in 21 experiments in which seven non-diuretic compounds were administered intravenously in doses of 1,2 and $4 \mathrm{mg}$. of mercury per kilo *

\begin{tabular}{|c|c|c|c|c|c|c|c|c|c|c|c|c|c|c|}
\hline \multirow{5}{*}{ p-Chloromercuri-benzoote } & \multirow{5}{*}{\begin{tabular}{c|} 
Dose \\
$\mathrm{moH}_{\mathrm{Kg}}$ \\
1 \\
2 \\
4
\end{tabular}} & \multicolumn{2}{|c|}{$\begin{array}{l}\text { Urine } \\
\text { Flow }\end{array}$} & & \multirow{2}{*}{\multicolumn{2}{|c|}{\begin{tabular}{|c|}
$\begin{array}{c}\text { Creatinine } \\
\text { Clearance }\end{array}$ \\
Cont. Max. \\
ca.min \\
\end{tabular}}} & \multirow{2}{*}{\multicolumn{2}{|c|}{ 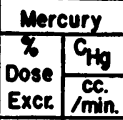 }} & \multicolumn{5}{|c|}{ Terminal Mercury Concentrotion } \\
\hline & & $\begin{array}{c}\text { Fic } \\
\text { Cont. } \\
\text { cc. } \\
\end{array}$ & Max. & \begin{tabular}{|l} 
Excre \\
Cont. \\
$\mu E q$ \\
\end{tabular} & Tox. & & & & & Plosme & \begin{tabular}{|l|} 
Renol \\
Cortex \\
$\mu g m . / c$
\end{tabular} & Spleen & $\frac{1 \text { Liverl }}{\mathrm{gm} .}$ & dolor \\
\hline & & 2.3 & 1.2 & 185 & 210 & 89 & 76 & 38 & 10 & 2.3 & 13 & 0.7 & 1.3 & 0,3 \\
\hline & & 2.5 & 0.3 & 350 & 20 & 76 & 51 & 36 & 12 & 4.1 & 36 & 2.1 & 2.8 & 0.8 \\
\hline & & 3.2 & 2.7 & 540 & 140 & 48 & 42 & 44 & 9 & 100 & 95 & 4.7 & 7.9 & 1.0 \\
\hline \multirow[t]{3}{*}{ Bromomercuri-methone } & 1 & 1.3 & 0.5 & 140 & 20 & 73 & 50 & 0.2 & 0.2 & 0.3 & 5 & 7.9 & 2.3 & 0.6 \\
\hline & 2 & 5.0 & 3.6 & 380 & 360 & 55 & 50 & $<.1$ & 0.2 & 0.6 & 21 & 30. & 9.2 & 1.5 \\
\hline & 4 & 2.5 & 1.2 & 380 & 66 & 34 & 25 & $<.1$ & 一 & 0.5 & 27 & 40. & 19. & 2.4 \\
\hline \multirow[t]{3}{*}{ Bromomercuri-benzene } & 1 & 4.8 & 3.1 & 590 & 500 & 53 & 46 & 0.2 & 0.1 & 0.8 & 36 & 7.3 & 6.2 & 1.1 \\
\hline & 2 & 5.6 & 4.6 & 470 & 250 & 63 & 55 & 0.7 & 1.0 & 1.7 & 51 & 20. & 9.8 & I.I \\
\hline & 4 & 5.5 & 2.1 & 360 & 51 & 67 & 35 & 2.7 & 4.5 & 2.5 & 97 & 18. & 27. & 2.2 \\
\hline \multirow[t]{3}{*}{ Bromomercuri-propane } & 1 & 1.1 & 1.7 & 140 & 60 & 63 & 50 & $<.1$ & - & 0.1 & 18 & 5.6 & 3.7 & 0.5 \\
\hline & 2 & 0.8 & 0.4 & 96 & 40 & 49 & 47 & $<.1$ & 0.3 & 0.2 & 37 & 8.2 & 5.7 & 0.7 \\
\hline & 4 & 1.2 & 0.2 & - & - & 58 & 30 & $<.1$ & - & 0.7 & 27 & 23. & 15. & 1.3 \\
\hline \multirow{3}{*}{$\begin{array}{c}\text { 3-lodomercuri-2-hydroxy- } \\
\text { propane }\end{array}$} & 1 & 1.2 & 0.3 & 210 & 15 & 37 & 25 & 0.6 & 1.3 & 0.2 & 24 & 2.7 & 2.7 & 0.3 \\
\hline & 2 & 2.2 & 0.9 & 200 & 80 & 57 & 57 & 0.4 & 1.5 & 0.4 & 54 & 70. & 9.8 & 2.4 \\
\hline & 4 & 2.1 & 1.8 & 240 & 96 & 43 & 40 & 0.4 & 1.0 & 1.1 & 91 & 160. & 15. & 1.8 \\
\hline \multirow{3}{*}{$\begin{array}{c}\text { 2-Chloromercuri-1-hydroxy- } \\
\text { ethane }\end{array}$} & 1 & 2.6 & I.I & 560 & 250 & 102 & 90 & 6.6 & 13. & 0.4 & 56 & 13. & 3.0 & 0.2 \\
\hline & 2 & 1.5 & 0.6 & 230 & 60 & 45 & 46 & 1.4 & 6.5 & 0.3 & 39 & 8.9 & 3.6 & 0.3 \\
\hline & 4 & 2.9 & 0.3 & 260 & 3 & 48 & 25 & $<.1$ & - & 1.7 & 104 & 35. & 22. & 2.0 \\
\hline \multirow{3}{*}{$\begin{array}{c}\text { 2-Chloromercuri-1-methoxy- } \\
\text { ethone }\end{array}$} & 1 & 1.9 & 0.8 & 450 & 96 & 77 & 72 & 2.9 & 9.0 & 0.2 & 35 & 16. & 2.1 & 0.8 \\
\hline & 2 & 1.5 & 0.7 & 150 & 54 & 77 & 73 & 0.5 & 1.7 & 0.4 & 59 & 38 & 5.9 & 1.0 \\
\hline & 4 & 1.7 & 1.1 & 93 & 124 & 70 & 70 & 0.2 & 1.0 & 0.6 & 152 & 62. & 19. & 23 \\
\hline
\end{tabular}

* See legend of Table III for further clarification. 


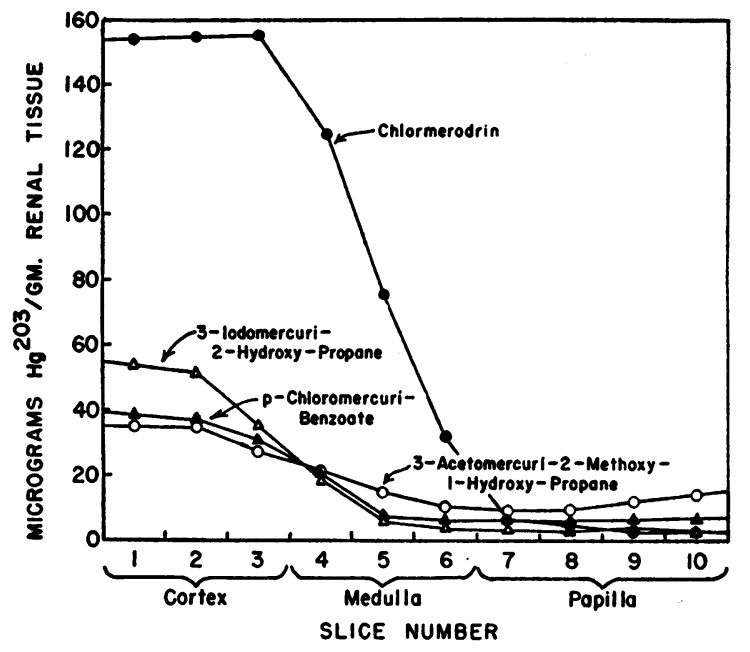

Fig. 5. A Comparison of the Distributions of Mercury in the Cortex, Medulla and Papilla of the KIDNEY Following the Intravenous Administration of Two Diuretic Compounds, Chlormerodrin aNd 3-ACETOMERCURI-2-METHOXY-1-HydROXY-PROPANE, AND Two Non-Diuretic Compounds, P-Chloromercuri-BenZOATE AND 3-IODOMERCURI-2-HydROXY-PROPANE

In each experiment an amount of the compound containing $2.0 \mathrm{mg}$. of mercury per kilo was administered 3 hrs. before sacrificing the animal to obtain the renal tissue. See text for description of method of sampling. Data derived from experiments summarized in Figures $1,2,3$ and 4.

which $2 \mathrm{mg}$. of mercury per kilo were administered as chlormerodrin, 3-acetomercuri-2-methoxy1-hydroxy-propane, p-chloromercuri-benzoate and 3-iodomercuri-2-hydroxy-propane. All compounds exhibited a qualitatively similar distribution, being most highly concentrated in the cortex, less in the medulla and least in the papilla. The last three of these compounds exhibited a quantitatively similar distribution, the two nondiuretics bracketing closely the diuretic. Thus, neither total concentration of the compound nor peculiarity of distribution could be related to diuretic activity.

\section{DISCUSSION}

A number of studies have demonstrated that mercurial diuretics are accumulated in kidney tissue and that diuresis occurs only after some undefined threshold concentration has been achieved (9). Results presented in this paper demonstrate that non-diuretic compounds of mercury are likewise concentrated in kidney tissue and that their distribution within renal cortex, medulla and pa- pilla is both qualitatively and quantitatively similar to that of diuretic compounds. Accordingly, binding by renal tissue is not a feature which distinguishes diuretic from non-diuretic compounds of mercury.

It is generally believed that the combination of inorganic mercury, split off from the diuretic, or of the free mercury bond of the intact diuretic molecule with renal sulfhydryl enzymes renders those enzymes inactive and results in diuresis (2). Recent evidence supports the thesis that the intact molecule rather than inorganic mercury is the active agent $(11,12)$. Our results demonstrate that compounds active in vitro as inhibitors of sulfhydryl enzymes are not necessarily diuretics in vivo. Thus of the four commonly used inhibitors of sulfhydryl enzymes in vitro, three, namely bromomercuri-methane, bromomercuri-benzeneand p-chloromercuri-benzoate, have no diuretic activity in vivo. If inhibition of sulfhydryl enzymes is a significant element of the diuretic process, then the inhibitor must have properties other than, or in addition to, those of the three compounds mentioned above.

All of the mercurial compounds which we have studied have been so highly bound to the plasma proteins that little could be filtered through the glomeruli; most of that which enters the urine must have been eliminated by tubular secretion. Of the 13 compounds studied, 6 with diuretic properties are rapidly excreted, while 6 of the 7 without diuretic properties are slowly excreted. One might infer that active tubular secretion of a mercurial compound leads to its accumulation in a region where enzymes significant for the reabsorption of salt and water are located. Blockade of these enzymes results in diuresis. Against this view is our finding that $\mathrm{p}$-chloromercuri-benzoate, which is not a diuretic, is rapidly excreted in the urine, presumably by the same mechanism responsible for the secretion of the several diuretic agents.

More or less by exclusion, we have been forced to the view that steric configuration is significant in determining whether or not a given compound of mercury will have diuretic properties. We suggest that some "critical lock and key" relationship ${ }^{8}$

8 Steric configuration might be related to diuretic activity in a number of ways other than by the mechanism postulated. Thus a hydrophilic group three carbons dis- 
exists which can be schematically represented as follows :

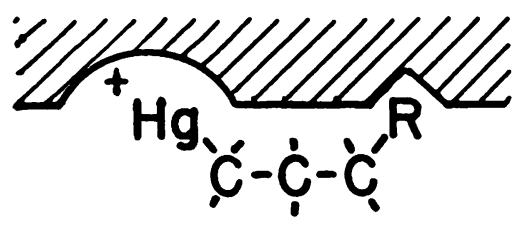

The simplest compounds which we have observed as having diuretic properties include the following:

and<smiles>CC=CCO</smiles><smiles>CCCCO</smiles>

These compounds exhibit a terminal mercurycarbon linkage, a free mercury valence and a hydrophilic substituent (in these instances an $\mathrm{OH}$ group) three carbons removed from the mercury. As pointed out in the introduction, this configuration characterizes the mercurial diuretics in common use today although the hydrophilic substituent is more complex than that of the compounds noted above. The simplest hydrophilic substituent in a clinically useful diuretic is urea, present in chlormerodrin.

The non-diuretic compounds most closely related to the two diuretics described above have the

tant might increase the dissociation of the terminal atom of mercury as free mercuric ion. It has long been considered that compounds of mercury are diuretics by virtue of the fact that they liberate small quantities of mercuric ion (2). Against this view is the recent evidence $(11,12)$ that mersalyl and meralluride are excreted either as cysteine or acetyl-cysteine complexes of the parent compound and that little or no inorganic mercuric ion can be found in the urine. Furthermore, it is evident in the data presented in this paper, that the diuretic activity of chlormerodrin and possibly of meralluride exceeds that of mercuric chloride per $\mathrm{mg}$. of mercury administered. It is difficult to believe that chlormerodrin could exert its marked diuretic effect by liberating a minute fraction of its mercury as mercuric ion. A more acceptable explanation of our findings would be that the bonding of mercury to an active enzyme site is facilitated by a hydrophilic group three carbons distant without the necessity of postulating secondary bonding to the enzyme through that hydrophilic group. following structures :

$$
\begin{aligned}
& +\mathrm{Hg}-\underset{\mathrm{H}}{\mathrm{C}}-\underset{\mathrm{H}}{\mathrm{C}}-\mathrm{OH}, \quad+\mathrm{Hg}-\underset{\mathrm{H}}{\mathrm{C}}-\underset{\mathrm{H}}{\mathrm{C}}-\mathrm{O}-\mathrm{CH}_{3} \\
& \text { and } \\
& +\mathrm{Hg} \underset{\mathrm{H}}{\mathrm{C}}-\underset{\mathrm{H}}{\mathrm{H}}-\underset{\mathrm{C}}{\mathrm{H}}-\mathrm{CH}_{3}
\end{aligned}
$$

The first two differ in having a two carbon rather than a three carbon chain. The third differs in having no hydrophilic substituent on the terminal carbon. Obviously to determine whether the three carbon chain is truly significant, it would be necessary to show that a 4-mercurated-n-butanol is not diuretic. To date we have been unable to synthesize this compound.

If steric configuration is significant in determining whether or not an organic compound of mercury will exhibit diuretic activity, why is bichloride of mercury a moderately effective diuretic? A simple answer might be that inorganic mercury binds readily to a single active enzyme site. Only when an organic side chain is attached to one mercury valence, does it become necessary to have a second polar binding group three carbons distant from the mercury in order to form a stable complex with the enzyme. Another possibility is that the diuretic substance is not mercuric ion but a monothiol complex of mercury. Weiner and Müller (11) have shown that Salyrgan and chlormerodrin are excreted in combination with cysteine and acetylcysteine. Were mercuric ion to complex with cysteine in a 1:1 molar ratio in the kidney, the resulting compound would exhibit in some respects the features of a diuretic as outlined above:<smiles>CC(CN)C(=O)O</smiles>

If it be permissible to replace carbon with sulfur, the chain of one sulfur and two carbons between the mercury and the hydrophilic amino group would constitute the usual three units.

In all fairness, we must point out that this hypothesis, which imputes diuretic significance to a three unit chain linking mercury and a hydrophilic group, is a tenuous one. It is possible that a chain of four or more units would be compatible with 
diuretic activity, for we have been unable to synthesize and test such compounds. Furthermore, certain compounds (13), most notably Novasurol, have been assigned structures which are in opposition to this thesis. In general, however, the structures of these compounds have not been well established; possibly they constitute no contradiction. Furthermore our criteria of diuresis are more restrictive than those applied by others. Compounds which others have claimed to be diuretics, might in our hands be devoid of diuretic properties. It is perhaps best to consider our thesis merely as a working hypothesis and to admit the possibility that other structures might well be consonant with diuretic activity.

\section{SUMMARY}

Twelve organic compounds of mercury and mercuric chloride have been studied with respect to diuretic properties, effects on renal function, regression of plasma concentration and tissue distribution in acute experiments on dogs. Each compound was administered intravenously in doses of 1, 2 and $4 \mathrm{mg}$. of mercury per kilo of body weight.

Six of the 13 compounds exhibited diuretic properties, seven did not. All compounds were accumulated in the kidneys and no relation between pattern of distribution or renal concentration and diuretic activity could be established. Those compounds which were slowly excreted in the urine exhibited no diuretic activity.

Three of the compounds most widely used as inhibitors of sulfhydryl enzymes in vitro were devoid of diuretic properties. If diuresis is related to inhibition of sulfhydryl enzymes, the inhibitors must obviously have properties different from those exhibited by the compounds studied.

Our studies and those of Weiner and Müller (11) and others (12) have led us to the view that diuretic activity of organic compounds of mercury is dependent on some fundamental structural configuration. Within the limits of our experience, namely 12 organic compounds of mercury, 5 of which were diuretics and 7 of which were not, the structure associated with diuretic activity includes (a) a chain of not less than 3 carbon atoms, (b) an atom of mercury attached to the terminal carbon of this chain and (c) some hydrophilic group not less than three carbons distant from the mercury.
Probably other structures are compatible with diuretic activity; however, many are not.

\section{REFERENCES}

1. Friedman, H. L., Relationship between chemical structure and biological activity in mercurial compounds. Symposium, New York Acad. Science, Oct. 1955, In Press.

2. Pitts, R. F., and Sartorius, O. W., Mechanism of action and therapeutic use of diuretics. Pharmacol. Rev., 1950, 2, 161.

3. Farah, A., and Maresh, G., The influence of sulfhydryl compounds on diuresis and renal and cardiac circulatory changes caused by Mersalyl. J. Pharmacol. \& Exper. Therap., 1948, 92, 73.

4. Hellerman, L., Chinard, F. P., and Deitz, V. R., Protein sulfhydril groups and the reversible inactivation of the enzyme urease. J. Biol. Chem., 1943, 147, 443.

5. Barron, E. S. G., and Kalnitzky, G., The inhibition of succinoxidase by heavy metals and its reactivation with dithiols. Biochem. J., 1947, 41, 346.

6. Threefoot, S. A., Ray, C. T., Burch, G. E., Cronvich, J. A., Milnor, J. P., Overman, W., and Gordon, W., Concentration-time course in the plasma of man of radiomercury introduced as a mercurial diuretic. J. Clin. Invest., 1949, 28, 661.

7. Weston, R. E., Grossman, J., Lehman, R. A., Ullmann, T. D., Halperin, J. P., and Leiter, L., Renal extraction and excretion of mercury in man following intravenously administered mercurial diuretics. J. Clin. Invest., 1951, 30, 1221.

8. Greif, R. L., Sullivan, W. J., Jacobs, G. S., and Pitts, R. F., Distribution of radiomercury administered as labelled chlormerodrin (Neohydrin ${ }^{8}$ ) in the kidneys of rats and dogs. J. Clin. Invest., 1956, 35, 38.

9. Borghgraef, R. R. M., Kessler, R. H., and Pitts, R. F., Plasma regression, distribution and excretion of radiomercury in relation to diuresis following the intravenous administration of $\mathbf{H g}^{\mathbf{2 0}}$ labelled chlormerodrin to the dog. J. Clin. Invest., 1956, 35, 1055.

10. Fourneau, E., and Melville, K. I., Studies in mercurial hemotherapy. II. The quantitative evaluation of mercurial diuresis and its relation to chemical constitution. J. Pharmacol. \& Exper. Therap. 1931, 41, 47.

11. Weiner, I. M., and Müller, O. H., A polarographic study of mersalyl(Salyrgan)-thiol complexes and of the excreted products of mersalyl. J. Pharmacol. \& Exper. Therap., 1955, 113, 241.

12. Handley, C. A., and Seibert, R. A., The urinary excretory products after meralluride administration. J. Pharmacol. \& Exper. Therap., 1956, 116, 27.

13. Goodman, L., and Gilman, A., The Pharmacological Basis of Therapeutics. New York, Macmillan, 1941. 